\title{
A Diáspora Portuguesa Em Três Romances Da Literatura Contemporânea: Pontos E Contrapontos
}

\author{
The Portuguese diaspora in three contemporaneous literature novels: \\ points and counterpoints
}

\author{
Alleid Ribeiro Machado* \\ * Fundação de Amparo à Pesquisa do Estado de São Paulo, FAPESP, São Paulo - SP, \\ 05468-140, e-mail: alleid@usp.br
}

\begin{abstract}
RESUMO: Em $O$ retorno (2011), Dulce Maria Cardoso convida-nos a conhecer a história de Rui, um adolescente "retornado" de Angola que, junto a sua família, é obrigado a recomeçar a vida em Portugal Continental, a partir de uma situação financeira precária e limitada. O cenário é a década de 70 e o conturbado período de retorno de mais de meio milhão de cidadãos portugueses, durante a descolonização dos antigos territórios ultramarinos em África. Neste artigo, analisamos a temática da diáspora na literatura portuguesa contemporânea, considerando como ponto de partida o contexto sociocultural constante no livro $O$ retorno. Para tanto, estabelecemos uma ponte, dentro de uma perspectiva comparatista, com dois outros romances que, de maneira diversa ou semelhante, tratam do mesmo tema: Pouca terra...Poucá terra, de Júlia Nery (1984), que traz para o centro da narrativa a história dos emigrantes portugueses na França, a partir da óptica de uma garota de nome Leonor, e Livro, de José Luís Peixoto (2012), que tem como foco central, dentre a multiplicidade de temas, o cenário da emigração em França e os desencontros amorosos entre dois jovens enamorados: Ilídio e Adelaide. O objetivo é traçarmos um panorama, iluminado pelos estudos culturais, que nos leve a compreender mais amplamente algumas questões que atravessam o romance de Dulce Maria Cardoso e, que, também presentes nos dois livros em pauta, dão-nos a medida da própria formação do romance português contemporâneo, a refletir a ideia de uma nação habituada, desde o seu passado mais remoto, a uma condição de mal-estar próprio dos que estiveram à mercê da fatídica experiência diaspórica.
\end{abstract}

PALAVRAS-CHAVE: mal-estar; diáspora portuguesa; romance português contemporâneo.

ABSTRACT: In $O$ retorno (2011), Dulce Maria Cardoso invite us to know the Rui's story, a Portuguese Angolan teenager that returned from Angola, together his family. He is compelled to rebuild his life in Continental Portugal, from a precarious and limited financial situation. The scenario was the seventies and the turbulent period of return of more than a half million of Portuguese citizens, during the decolonization of former Portugal overseas territories in Africa. In this paper, we have analyzed the theme of diaspora in the contemporaneous Portuguese Literature, considering as the start point the sociocultural context contained in the book $O$ retorno. Thus, we have established a bridge with two other novels, within a comparative perspective, in order to find similarities or dissimilarities among them, once they address the same theme: Pouca

Volume 18

Número 40 


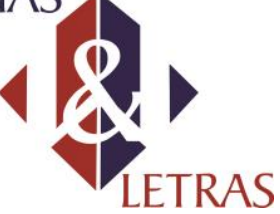

terra...Poucá terra, by Júlia Nery (1984), that brings to the center of the narrative the emigrants story from France, under the approach of a girl called Leonor, and Livro, by José Luís Peixoto (2012), which has the main focus, among the multiplicity of themes, the emigration scenario from France, and the loving disagreements between two young lovers: Ilídio and Adelaide. The goal is to sketch a viewpoint, clarified by the cultural studies, which conduct us to understand more largely some questions which come by the Dulce Maria Cardoso novel, and also the two other books in question. They give us the measure of the construction of the contemporaneous Portuguese novel, and reflect the idea of a nation which uses to have a condition of discomfort. This discomfort is proper to who are at the mercy of the diasporic fateful experience, since the most remote past.

KEYWORDS: discomfort; Portuguese diaspora; contemporaneous Portuguese novel.

Este artigo traz para o campo de análise alguns autores portugueses contemporâneos que têm procurado estabelecer um diálogo com o passado nacional português, principalmente tangido pelas questões diaspóricas, como demanda de um império que fora talhado tanto por poder e magnitude, quanto por dor e tristeza. Dulce Maria Cardos, Júlia Nery e José Luís Peixoto mostram-nos nos romances $O$ retorno (2011), Pouca terra...poucá terra (1984) e Livro (2012) um desejo claro de, sobretudo, relativizar a história recente, oferecendo-nos sobre os fatos possíveis versões e sobre a verdade diversas interpretações. Nessa toada, ao falarem de questões históricas específicas do cenário nacional português, atingem a totalidade humana, na identificação do mal-estar e da dor nos processos de deslocamento de uma terra para outra.

No caso do romance $O$ retorno (2011), situado historicamente na década de 70, temos oportunidades de visitarmos o cenário em Portugal de mudanças que viriam a por fim no regime salazarista, promovendo um período de liberdade por vias democráticas. Mais precisamente, o romance tem início na virada do ano de 1974 para 1975, já passado, portanto, o 25 de abril. Nesse momento, o país encontrava-se em meio a um lento processo de redemocratização e assistia também a uma mudança radical nos territórios antes colonizados. No caso de Angola, um dos principais cenários do romance, em poucos meses, cerca de trezentos mil portugueses que lá habitavam são obrigados a retornar de mãos vazias para Portugal. Assim, no livro em questão, Rui, nascido em Angola e filho de portugueses, acompanhará de perto esse doloroso processo de retorno à metrópole de muitos portugueses que, como a sua própria família, construíram as suas vidas em Luanda. 
Na mesma noite em que o sr. Manuel partiu com a família no Príncipe Perfeito, fomos à farra da passagem do ano [...] o pai olhava para a multidão que dançava na festa [...] o conjunto desafinava mas ninguém deixava de dançar por causa disso, estava à toa na vida o meu amor me chamou, pra ver a banda passar cantando coisas de amor [...]1975 ia ser um ano bom, se calhar o melhor de nossas vidas, íamos deixar de ser portugueses de segunda, o futuro era aqui [Luanda], o pai estava certo apesar dos chaimites e dos tiros [...] Só que a banda nunca mais passou. Foi tudo tomando o seu lugar, cada um de nós no seu canto e em cada canto uma dor [...] os tiros e os morteiros não pararam, os pretos continuaram a vir de todo o lado e os brancos a irem-se embora, os tropas portugueses já nem da bandeira queriam saber e os comunistas da metrópole vieram para cá [...]. O pai calou-se sobre o futuro (CARDOSO, 2011, p. 29-33).

Como observarmos, o trecho em destaque evidencia um momento importante na vida de Rui e de sua família, além dos efeitos da revolução. De um lado, existia ainda certa esperança cega de dias melhores em Luanda, alguma certeza de que as bases lá fixadas seriam reafirmadas, que as sementes ali lançadas ainda dariam frutos; de outro, a certeza dos ecos de uma guerra que já se fazia ouvir, a clareza da debandada de muitos portugueses para a metrópole. Temos, assim, a impressão de que o discurso de Rui suscita implicitamente outro, de ordem histórica. Como se sabe, Portugal sempre esteve à sombra de um passado glorioso, que se colocava como paradigma para as projeções temporais do presente e do futuro.

Dessa forma, estar preso ao passado equivaleria a estar preso a um modelo idealizado: a do país colonizador, com seus heróis e mitos, com suas batalhas e conquistas, que, no caso de $O$ retorno, simbolicamente se fazia representar pela nação outrora conquistada: Angola. Não é por outra razão que Rui e seu pai não querem acreditar no processo de descolonização. Para eles, o passado ainda faz sombra no presente, portanto, o império não poderia ter chegado ao fim.

Essa esperança misturada ao sonho do colonizador, de prosperar a sua presença e onipresença numa terra que seria a garantia da riqueza do império colonial, no entanto, vai sendo pouco a pouco atravessada por uma realidade das mais concretas e árduas: o processo de descolonização era evidente e já corria largamente Angola adentro. As palavras finais de Rui na citação em epígrafe dão mostras da dor que foi envolvendo e desbotando os sonhos e as esperanças futuras, tanto que o pai, o centro estabilizador da família, "calou-se" diante do amanhã.

Sem saída, a família decide seguir o mesmo destino dos portugueses em Luanda. Assim, Rui embarca com sua mãe e irmã para a metrópole, levando consigo poucos 


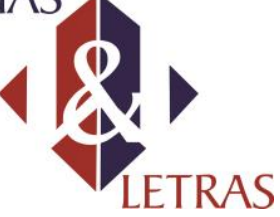

bens e diminutas esperanças, deixando para trás o pai, preso por suspeita de ação contra os negros: "quando voltei a mim o pai estava a ser metido no jipe com a sua própria arma apontada na cabeça" (CARDOSO, 2011, p. 76).

Rui é o protagonista de uma história que se divide na ambivalência geográfica entre um lá, Luanda, a terra da infância e dos primeiros amores; e um cá, a metrópole. Na perspectiva do romance, Lisboa sugere um novo espaço, marcado pelas lembranças de Rui em torno de seu passado e pelo seu desejo angustiante de toda uma vida que deveria seguir adiante. Como nos mostra a história, e como aconteceu com muitos retornados, Rui e sua família ficam hospedados num hotel. O cenário, talvez idílico da metrópole, construído em seu imaginário ao longo da vida passada em Luanda, portanto, logo será substituído por uma realidade das mais hostis, ou seja, por uma terra bem diferente dos mapas da aula de geografia.

Portugal não é um país pequeno, era o que estava escrito no mapa da escola, Portugal não é um país pequeno, é um império do Minho a Timor [...]. Um império tão grande como daqui até à Rússia não pode ter uma metrópole com ruas onde mal cabe um carro, não pode ter pessoas tristes e feias, nem velhos desdentados nas janelas tão sem serventia que nem para a morte têm interesse (CARDOSO, 2011, p. 83-84).

A família de Rui é recebida pelo IARN, o Instituto de Apoio ao Retorno de Nacionais, sendo encaminhada para um hotel de cinco estrelas no Estoril, abarrotado de retornados.

Sejam todos muito bem-vindos a este hotel. Façam o favor, entrem, podem sentar-se nessas poltronas [...] estejam à vontade [...] Sei pelo que estão a passar mas infelizmente não são os únicos. Não se preocupe com a mala minha senhora, o recepcionista toma conta delas. São circunstâncias terríveis mas não está ao alcance de nossa vontade mudá-las. São tempos conturbados [...] No meio do azar ainda tiveram sorte (CARDOSO, 2011, p. 67-69).

$\mathrm{Na}$ verdade, o hotel assemelha-se a um campo de refugiados, tornando-se um espaço de degradante frustração. O quarto 315 passa a ser a nova casa de Rui: "um quarto pode ser uma casa e este quarto e esta varanda de onde se vê o mar é a nossa casa" (CARDOSO, 2011, p. 165). É nesse espaço que o adolescente aprenderá a viver cada dia, a adolescer por hora, na espera assombrada pelo retorno do pai. Enquanto isso, o garoto vai reinventando a vida passada e os amigos de Luanda, refazendo as suas histórias, reaprendendo a amar e a enfrentar a nova realidade, conjugada no tempo presente à sombra das lembranças de Luanda. 


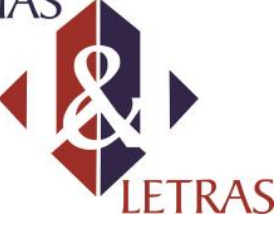

e-ISSN: 1981-4755

DOI: $10.5935 / 1981-4755.20170012$

Vou dar pontapés em todas as portas até chegar ao pátio do recreio, a puta da professora mandou-me para a rua com uma falta a vermelho mas eu vingo-me [...] A puta da professora, um dos retornados que responda, como se não tivéssemos nome, como se não bastasse ter-nos arrumado numa fila só para retornados (CARDOSO, 2011, p. 140).

A África torna-se cada vez mais o pretérito desejado, mas para sempre perdido. $\mathrm{O}$ romance instaura e partilha a dor causada pelo sentimento de perda. Uma perda relacionada não apenas a casa, aos bens ou aos sonhos de Rui. Em grande escala, essas perdas simbolizam na narrativa a subtração de algo muito maior e inimaginável: a de um país e de tudo o que nele ficou plantado. Além disso, $O$ retorno denuncia algo que aconteceu e que não pode ser olvidado. Pela voz de Rui, porta-voz duma história que todos deveriam se lembrar, as cicatrizes de uma geração, que hoje está praticamente esquecida, vão sendo abertas, dando margem para um questionamento em torno da história dos retornados.

Já é mais do que notória a ideia de que Portugal sempre esteve ligado ao seu passado grandioso e que tal sentimento continua presente no imaginário lusitano, como algo a ser resgatado para um futuro melhor. A saudade de um tempo ancestral, mítico e glorioso é marca da nação portuguesa, como nos lembra Eduardo Lourenço (1999). Se a identidade de uma nação está ligada a esse sentimento, analogamente as identidades dos sujeitos carregam consigo os arquétipos de sua nação. E, assim como Luanda se torna o não-lugar do decadente império, a metrópole correlativamente se torna o não-lugar de Rui, que faz parte de um grupo de pessoas, filhos de Portugal, que tiveram de regressar de mãos vazias a um país cujo império não lhes pode oferecer mais do que vergonha e hostilidade.

Não é por outra razão que a desconfiança por tudo e por todos passa a ser o sentimento mais comum a Rui. Se de um lado ele, sua mãe e irmã deveriam sentir-se à vontade numa terra que fora e era a de seus antecedentes, a hostilidade e a estranheza desse próprio povo face aos retornados acabam por trazer à tona, contrariamente, o sentimento de não-pertencimento. As raízes identitárias da família, principalmente as de Rui e de sua irmã, ainda estavam fincadas em Luanda e isso fazia com que eles se sentissem "estrangeiros" em Portugal.

Mas há uma possível explicação para a crise vivenciada por Rui, se a relacionarmos à questão diaspórica. Segundo algumas reflexões de Stuart Hall encontradas no livro Da diáspora (2011), a identidade cultural construída na terra de 


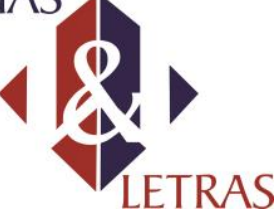

origem deverá ser mantida na nova terra, como esforço contínuo de pertencimento. Nesse sentido, o autor adverte:

Contudo, seria errôneo ver essas tendências como algo singular ou não ambíguo. Na situação da diáspora, as identidades se tornam múltiplas. Junto com os elos que as ligam a uma ilha de origem específica, há outras forças centrípetas: há a qualidade de "ser caribenho" [...] que eles compartilham com outros imigrantes do Caribe (HALL, 2011, p. 26-27).

Para Hall, as identidades sofrem as influências e as interferências diaspóricas. Embora o autor esteja falando de uma questão que tem como referência o povo caribenho, é possível alargarmos o escopo de sua reflexão, uma vez que, para o autor, tal sentimento pode ser experimentado por qualquer sujeito em face da vivência diaspórica: "essa é a sensação familiar e profundamente moderna de deslocamento, a qual - parece cada vez mais - não precisamos viajar muito longe para experimentar" (HALL, 2011, p. 27). Dessa forma, o outro lado dessa questão é a tentativa de se religar à terra de origem sofrida por aqueles que retornam. No que se refere a Rui, mesmo tendo saído de um país que era o seu e ido para outro que, na visão colonialista, também o era, havia entre as duas culturas, a africana e a portuguesa, dessemelhanças, cores e costumes diferentes. Se de um lado o novo país-exílio passou a ser um espaço para reafirmação identitária de Rui, por outro, Luanda continuaria a representar o lugar idealizado da saudade: "nunca mais podemos voltar, a nossa casa já não existe, a mãe fica zangada, estás a arreliar-me, e eu, a nossa vida lá acabou é melhor esquecer a casa e as saudades que tem da casa, tem de se esquecer de tudo" (CARDOSO, 2011, p. 163).

Esse objeto de reflexão - o mal-estar ou o sentimento de não-pertencimento, aparece mencionado também em autores como Edward Said. No ensaio homônimo que intitula o livro Reflexões sobre o exílio, Said analisa cuidadosamente a condição do exílio, associando a ela a questão do nacionalismo, como uma experiência traumatizante e dolorosa que se faz na tensão entre o ser e o seu verdadeiro lar e o novo espaço de vivência. Tal experiência, para Said, acabou por ser tema da modernidade tardia período paradoxalmente associado às incertezas, à alienação e à ausência de vínculos por justamente ser "em larga medida, obra de exilados, emigrantes, refugiados" (SAID, 2003, p. 46). Nesse sentido, o autor ressalta que exilados sempre existiram em outras épocas, a diferença é que:

[...] a diferença entre exilados de outrora e os de nosso tempo é de escala: nossa época, com a guerra moderna, o imperialismo e as ambições quase teológicas dos governantes totalitários, é, com efeito, 


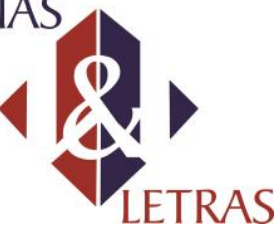

a era do refugiado, da pessoa deslocada, da imigração em massa (SAID, 2003, p. 47).

Diante do exposto, entendemos que, no caso do romance de Dulce Maria Cardoso, a questão do não-pertencimento, do sentimento de mal-estar ou de desconforto de Rui, metaforicamente sugerem e fazem ressurgir no século XXI a lembrança da perda do império colonial. Se a mobilidade geográfica se define, como lembra-nos Said, como uma condição política associada ao nacionalismo, uma vez que "o nacionalismo é uma declaração de pertencer a um lugar, a um povo, a uma herança cultural” (SAID, 2003, p. 49), é nessa conjuntura que Rui, inevitavelmente, rechaça o Portugal dos revolucionários - responsáveis pelo fim do sonho colonial.

A puta da professora, um dos retornados que responda, como se não tivéssemos nome [...]. A puta a justificar-se, os retornados estão mais atrasados, sim, sim, devemos estar, devemos ter ficado estúpidos como os pretos, e os de cá devem ter aprendido muito depois da merda da revolução [...]. Ainda agora não há um dia em que não haja manifestações, bombas, ameaças, expropriações, ocupações, greves, há sempre comunicados na televisão, já não é só do MFA, do Conselho da Revolução, do Copcon, agora é das comissões, dos comitês, das cooperativas, são cada vez mais, não sei onde vão buscar tantos revolucionários (CARDOSO, 2012, p. 140).

Portanto, se o nacionalismo se constitui na dinâmica do pertencer, pois tem seus pais fundadores e seus textos de base; o exílio existencial vivenciado por Rui constituise, em oposição, na lógica do não-pertencimento, com os seus inimigos e heróis, "marcos históricos e geográficos" (SAID, 2003, p. 49). Por fim, se o nacionalismo fazse na conjuntura do coletivo, portanto, dos que nunca deixaram Portugal, aos retornados impõe-se uma experiência vivida fora do grupo, demandando sempre, e exatamente por isso, um estado de solidão:

este quarto com esta varanda de onde se vê o mar não é uma casa. Muito menos a nossa casa. Se fosse a nossa casa devia ser bom fumar um cigarro como quando fumava no muro da tabacaria do sr. Manuel. Mas assim é diferente, assim é fumar um cigarro num sítio a que não pertenço e a que nunca pertencerei (CARDOSO, 2012, p. 172).

Tal quadro, no entanto, deverá ser revertido em $O$ retorno, uma vez que a crise vivenciada por Rui terminará com a volta do pai para junto da família.

Ninguém volta da morte mas o pai está à porta do nosso quarto. Um saco de viagem preto na mão, uma boina cinzenta e um casaco aos quadrados. Não consigo acreditar que é o pai, o pai que os pretos levaram com as mãos amarradas atrás das costas [...] o pai que eu tive 


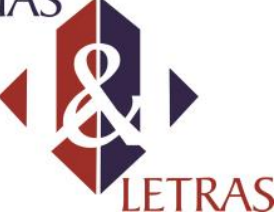

de julgar morto. Chamo a mãe e a minha irmã, é o pai, o pai chegou, o pai veio ter conosco [...]. O pai vai tirar-nos daqui (CARDOSO, 2012, p. 220-22; 234).

O retorno do pai para Portugal sugere-nos, par além da própria estabilidade emocional dos membros da família, o desejo implícito de consolidação dos ares democráticos e libertários proporcionados pelo 25 de abril. A palavra "pai” possui relação etimológica com a palavra "pátria". Considerando o contexto histórico-político do romance, concomitante à volta do pai está sugerido nas entrelinhas do romance o desejo de estabilidade da pátria portuguesa. Se a perda do pai gerou o caos em Rui e em sua família, a perda de um império foi o caos paulatinamente suprimido pela Revolução dos Cravos, que devolveu aos portugueses o sentimento de estabilidade e de controle do Estado.

Pelas razões expostas, $O$ retorno fecha-se toldado pela esperança. Rui e sua família deixam o hotel e iniciam uma nova vida, entre dificuldades, sonhos e esperanças. De qualquer forma, a nova realidade configura-se pelo desejo de seguir adiante, afinal "o futuro pode ser onde se quiser" (CARDOSO, 2011, p. 266). A esperança realista de Rui, que não se confunde com um otimismo ingênuo, endossa o desejo autoral de dar a narrativa um sentido de recomeço. Esse interesse da autora aparece mencionado numa entrevista concedida por ela, que está publicada na Revista Desassossego. Nela, Dulce Maria Cardoso afirma que não lhe interessa fazer uma história sem que haja a possibilidade de recomeço, uma nota de esperança:

$O$ retorno só me interessa por ter muito que ver com o recomeço. N'O retorno, só me interessa a perda na perspectiva do recomeço. A perda por perda não me interessa [...] Interessa-me ir até os mais profundos dos abismos, mas desde que haja um caminho de volta, senão já chega a realidade como está (MACHADO, 2014, p. 108).

Os sentimentos experimentados por Rui também estão presentes em dois romances da literatura portuguesa contemporânea e, por isso, parecem flertar com as temáticas elucidadas até aqui. Como já procuramos explanar no início deste artigo, na esteira d'O retorno, podemos mencionar: Pouca terra... poucá terra (1984), de Júlia Nery e Livro (2012), de José Luís Peixoto. Esses dois romances, que tratam do contexto da emigração portuguesa em França ${ }^{1}$, têm como traço comum a tensão permanente entre

\footnotetext{
${ }^{1}$ A questão da emigração portuguesa em França foi recentemente abordada pelo cinema português na produção de Ruben Alves: A gaiola dourada (2013), que conta a história de um casal de emigrantes portugueses na França, interpretados por Rita Blanco e Joaquim de Almeida, que a certa altura dos Volume 18

Número 40
} 


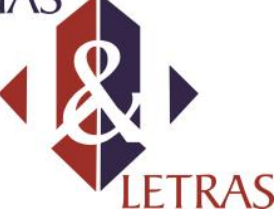

e-ISSN: 1981-4755

DOI: $10.5935 / 1981-4755.20170012$

o lá e o cá. Mas apenas no caso do livro de Júlia Nery, essa tensão traduz-se também pelo sentimento de mal-estar e não-pertencimento.

Pouca terra...poucá terra abre-se com uma citação de Rabbi Joshua Ben Hamaniah, um judeu do século I, em que se lê: "Os homens foram criados a partir do pó. Ora, o pó depressa amolece. Eva foi criada a partir de um osso. Sobre o osso podese deitar quanta água se queira, ele não amolecerá’. Na verdade, tal citação introduz o leitor no universo feminino do romance, em que se é possível conhecer a história de uma geração de mulheres de uma família natural da Beira Baixa, formada pela avó, Maria Menina, a matriarca, as suas duas filhas: Maria da Luz e Maria das Dores, e a sua neta: Leonor. Secundariamente, fazem-se presentes na história os homens: o marido de Maria Menina, Joaquim Manco, e o marido de Maria da Luz, Edgar.

A história tem início com a viagem de comboio de Leonor a Lisboa, durante suas férias escolares, nos anos 60. Estruturalmente, a narrativa divide-se em capítulos, nomeados como estações. Cada parada que o comboio faz de Paris a Lisboa, representa um flash da memória de Leonor. Ao todo, o romance possui 22 estações, abrindo-se com a estação "Pouca terra...poucá terra", a representar 'onomatopeicamente' o som da comboio que levava os emigrantes portugueses à França; e encerra-se ciclicamente com a parada de mesmo nome, na verdade, o ponto de partida, o regresso de Leonor.

É pela perspectiva de Leonor, uma jovem universitária, que conhecemos a história de uma geração de mulheres. As rememorações da garota centram-se na história que ela ouviu desde menina de Maria Menina - uma portuguesa analfabeta cujas imposições sociais e culturais de seu meio, o ambiente das vilas portuguesas, fora constantemente afrontadas pelo seu gênio emancipador. Maria Menina é um exemplo de força e coragem para a sua família, por justamente romper, dentro de seus limites, com os paradigmas de comportamento esperado para as mulheres de seu tempo. Para além da questão de gênero, muito perceptível no comportamento emancipador de Maria Menina, encontramos fortemente marcada a questão do não-pertencimento em Leonor.

A jovem, que há pelo menos dez anos, é obrigada a voltar para Portugal a fim de não perder contato com as suas raízes, não consegue se acostumar com a ideia de ter de deixar a França, onde estuda e já construiu laços de amizade. Seu drama pessoal, portanto, faz-se pela necessidade de dar voz e corpo aos seus próprios sonhos no lugar de continuar submissa aos da avó:

acontecimentos, diante da oferta de uma herança inesperada, veem-se no dilema de abandonarem o que construíram em França e retornarem a Portugal.

Volume 18

Número 40 


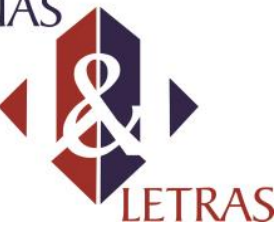

e-ISSN: 1981-4755

DOI: $10.5935 / 1981-4755.20170012$

Como poderia ela gozar a vida, desfrutando-a plenamente sem os entraves que carregava desde menina - dar vida aos sonhos alheios? Não poderia também, como os seus companheiros das barricadas de maio, assumir plenamente a insurreição contra as instituições e os hábitos (NERY, 1984, p. 12).

O sentimento de inadequação de Leonor concretamente aparece em certo trecho do romance, quando é possível visualizarmos, durante a viagem da garota para Lisboa, o registro de sua insatisfação:

"interdit d'interdire" - [...] E sentia quando traçava as letras a tinta negra que, para si, muitas coisas eram interditas porque não tinha ainda encontrado o seu lugar, o espaço físico e mental onde mergulhar as suas raízes (NERY, 1984, p. 12)

$\mathrm{Na}$ gare de Estraburgo, Leonor observa grupos de rapazes e raparigas que, ao contrário de si, achavam-se muito à vontade num chão que era deles também:

um bando de poliglotas, espalhando-se pela Europa durante os meses de férias [...] todos eles presos à terra onde tinham nascido por amarras elásticas, projetando-os por esse mundo fora com certeza de ida e volta. Podiam partir confiantes de reencontrar o lugar onde pertenciam (NERY, 1984, p. 12).

Tal certeza não era partilhada pela jovem. Ela foi trazida para França ainda muito pequena com carimbo de emigrante e, depois de instalada, impôs-se lhe o destino de pertencimento à terra de seus avós. Por isso, partia sempre contrariada para Portugal, a cada 2 anos, quando sua alma exigia que ficasse em França, partilhando com seus amigos franceses a vida e o cotidiano que lhes era comum: "Cathy, Philippe, Monique e Claude deveriam juntar-se agora no cafezinho do square a fazer planos para outubro" (NERY, 1984, p. 13).

Por mais que Maria Menina tivesse boas intenções no que se refere ao desejo de que a menina não perdesse suas raízes portuguesas, reconhecidas, inclusive, pela garota, o mal-estar de Leonor dizia respeito à falta de poder de decisão:

- Leonor, tu que és estudada, não podes ter a mesma vida da tua mãe..., que já não falo da minha... Olha que eu quero ter de contar da minha neta...mas coisas boas, que tudo podes chegar onde quiseres (NERY, 1984, p. 16).

O desejo de não ir para Portugal, além de sugerir, numa leitura mais rasa, uma aversão da garota, que se sentia francesa nos modos, a um povo "cada vez mais pálido e triste", um povo que se "esvaía em homens, andados pelas sete partidas do mundo" (NERY, 1984, p. 16); sugere uma repulsa a uma nação que carregava o estigma de ser o Volume 18

Número 40 


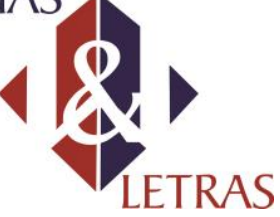

quintal da Europa. Depois do envolvimento no maio de 68 a garota passou a sentir-se parte da engrenagem estudantil francesa. A participação, junto a seus amigos franceses, numa causa francesa conferiu-lhe o status de cidadã e, mais do que isso, dera-lhe a possibilidade de ser protagonista de seus atos e de poder responder por todas as possíveis consequências: "Leonor recordou os anos em que vivera no espaço de um mês. Fora uma libertação, uma catarsis: pudera tomar a palavra, testemunhar, gritar, protestar, de mãos dadas, num êxtase coletivo" (NERY, 1984, p. 18, grifo da autora).

Já em Lisboa, Leonor nota que nada era igual ao que deixara: "queria ficar na sua rua, na sua cidade, mas não sabia já onde pertencia, transplantada no cedo da sua vida para uma terra que às razões da sua cabeça convinha, mas que aos seus sentidos desagradava" (NERY, 1984, p. 23). A evidência de seu mal-estar pode ser observado no seguinte trecho: "Era francesa pela cultura, não pelo sentir. Francesa pelo falar, não pela língua. Estava sem saber onde seria o seu lugar. Reencontrou a sua casa que já não era a mesma - transformada num apartamento moderno" (NERY, 1984, p. 24). A casa em Portugal era a segurança de um possível retorno futuro. E a família ia decidindo o futuro de Leonor, que havia de se casar e trabalhar em Portugal, que haveria de fincar, enfim, as suas raízes para longe da França. No fim das contas, a jovem protagonista do romance estava mesmo farta que lhe mexessem no destino:

sentindo-se estranha na sua casa reencontrada. Queria projetar-se para fora de si e compreender-se [...]. Como se desprenderia da terra francesa, onde os amigos, os interesses e os hábitos eram como parte de si? (NERY, 1984, p. 25).

Em última instância, a dúvida de Leonor dizia respeito a esse desajustamento identitário. Não sabia como organizaria a sua vida dali a alguns meses. Uma carta sua escrita assim que chegara em Lisboa a sua amiga francesa Cathy, dá conta desses conflitos:

Cathy: Cheguei em Lisboa e na bagagem não trouxe nem sonhos, nem projetos; apenas os sentidos alerta e de alforges bem grandes para levar comigo quanto puder do sol, dos cheiro e da minha gente reencontrada. Bem pouco restam dos que eu conheci e que me conhecem ainda. Aqui sou tratada com a deferência distanciada que se dá a uma gente estrangeira; aí com um meio desprezo pelo cheiro a emigrante que nem o desodorante, nem os diplomas conseguem disfarçar. Sou agora na minha terra uma estranha: não tenho amigos nem hábitos que me permitam radicar-me, mas queria ficar; quando penso em regressar a França, sinto uma lassidão, um pouco querer a prender-me a vontade. Por outro lado, há em mim um grande desejo de voltar e desfrutar um pouco do conseguimos em maio; para continuar a luta [...] (NERY, 1984, p. 26).

Volume 18

Número 40 


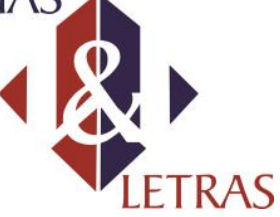

A carta escrita a Cathy também dá a medida do olhar de Leonor em torno do "clima" que encontrou em Portugal relacionado, sobretudo, ao contexto das guerras coloniais:

As pessoas de cá já não têm a mesma alegria, gastas pelo luto de uma guerra meio disfarçada e pela inibição de pensar. Vão-se de cá para aí, para ali, sempre mais longe os melhores braços e as melhores cabeças; e para além do mar os jovens [...]. E onde um lugar onde me sinta plantada, de corpo e espírito a frutificar, espreguiçadas as raízes em terra própria? Agora ainda não sei onde pararei. Não poderei ficar por cá, que asfixio; não poderei ficar por aí, que murcho, ao saber-me definitivamente cortada das minhas raízes [...] (NERY, 1984, p. 27).

Todas as mudanças ocorridas em Portugal são para Leonor motivações para reafirmar o seu sentimento de inadequação. Estava em Lisboa, entretanto as lembranças continuavam a levá-la para além dos Pirineus. Tinha chegado a pouco, mas só pensava em voltar "tinha medo de não aguentar até à chegada dos pais nesta cidade que já não lhe dizia nada" (NERY, 1984, p. 35). Arriscava um passeio pelas ruas, na esperança de reviver algo que não sabia exatamente o que era, talvez de se reencontrar: "mas a rua não era a mesma: as casas atarracadas e coloridas tinham sido substituídas por blocos de apartamentos e já não havia mulheres demorando-se às janelas" (NERY, 1984, p. 35).

De volta à realidade do comboio que agora a transportava de volta à França, fecha-se o ciclo das lembranças de Leonor. Ainda indecisa, a garota não se decidira sobre o seu futuro na França ou em Portugal: "E se um dia, quando finalmente tivesse a coragem de decidir-se a ficar, fosse obrigada a regressar?” (NERY, 1984, p. 160). Há anos que Leonor arrastava nos comboios das férias a mesma dúvida. A lembrança da conversa com Cathy, principalmente na parte que lhe colocava dúvidas acerca de um futuro duvidoso em França: “e depois?”, de certa forma gerava em Leonor a intranquilidade de não ser francesa. O que poderia dizer à amiga francesa? Que resposta poderia dar a si mesma? Nos poucos dias que esteve em Portugal teve tempo, ao andar pelas ruas soalheiras, ao rever aquela gente, ao dar asas às lembranças de sua família e de suas raízes, de formular uma resposta:

- E depois muitos filhos de portugueses nasceram já em França, e alguns optam pela nacionalidade francesa. E depois, minha amiga francesa, nós entraremos pelo vosso sangue, pela vossa língua, pela vossa História, pelos vossos hábitos, que o português é semente que em qualquer terra dá fruto (NERY, 1984, p. 161). 


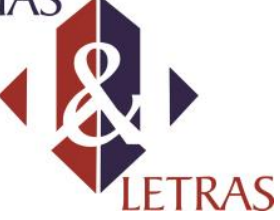

Se a Europa, à altura dos anos cinquenta, abria as suas fronteiras para deixar entrar mão de obra que iria, ao longo dos anos, contribuir para o desenvolvimento desses países, Portugal estimulava a saída de muitos portugueses, a fim de conseguirem trabalho, principalmente para a França. O objetivo principal de voltar para Portugal acabou, para muitos, por ser um projeto adiado e, em alguns casos, posto de parte. $\mathrm{O}$ romance de Júlia debruçou-se sobre os filhos destes migrantes portugueses residentes em França que, apesar de estarem plenamente inseridos na sociedade de acolhimento dos seus progenitores, preferiram vir para Portugal sem que, todavia, os seus pais seguissem as suas pisadas. Em entrevista à Revista Desassossego, Júlia Nery afirma que, aquando da escrita do romance, objetivou dar uma causa mais nobre à emigração portuguesa em França do que aquela meramente relacionada à questão monetária. Por isso, quis enfatizar a importância dos estudos de Leonor.

Há quinze dias participei de uma tertúlia e falei acerca dessa motivação, ou da realidade como inspiradora, e eu expliquei exatamente como a realidade havia motivado a escrita de "Pouca terra...". Quando eu estava em França, em 1980, com uma bolsa de estudos, fui assistir a uma conferência, em Vichy, de membros da extrema Direita, e acabei por ouvir um ferrenho discurso contra os emigrantes. Eu estava revoltada, mas não podia dizer nada, até por medo, pois estava ali sozinha. Mas na minha cabeça começou a surgir uma "leitmotiv": o português é a semente que em qualquer terra dá fruto. Eu dizia isto e parecia um refrão. Naquele mesmo dia, quando cheguei ao hotel, comecei a escrever um texto como uma espécie da catarse em torno de tudo aquilo que havia acontecido e, naquela altura, não percebi que era, na verdade, o começo do romance. Comecei a escrever o romance como uma resposta ao Monsieur Pen ${ }^{2}$. Tudo isso motivou a escolha das personagens. Não podiam ser emigrantes que só pensavam em voltar para Portugal com muito dinheiro. Por isso, [no livro] o pai de família ${ }^{3}$ vai andar envolvido nas lutas sindicais de 78 , a rapariga ${ }^{4}$ estuda sociologia e quer integrar-se à vida francesa, e são pessoas que pensam a vida para além da casa "muito maison". Quis escolher personagens que emigraram por motivos especiais, por "mais altos motivos", digamos (MACHADO, 2014, p.111).

O romance propositalmente termina em aberto, não ficando clara a decisão tomada por Leonor. Dessa forma, não há uma resolução definitiva para a história da adolescente. Obviamente, o desfecho em aberto, além de permitir diversas possibilidades de interpretação, também sugere a permanência do conflito e do sentimento de mal-estar. A identidade de Leonor vai sendo talhada no espaço da

\footnotetext{
${ }^{2} \mathrm{O}$ responsável pelo discurso contra os emigrantes.

${ }^{3}$ Referindo-se $a$ Edgar, casado com Maria da Luz, filha de Maria Menina, protagonista do romance.

${ }^{4}$ Referindo-se à Leonor, filha única de Edgar e Maria da Luz, portanto neta de Maria Menina.

Volume 18

Número 40
} 


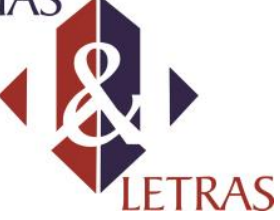

fronteira entre o lá e o cá, na ambivalência entre pertencer e não-pertencer, refletindo um tempo de incertezas.

Com propósitos, em certa medida, diferentes, José Luís Peixoto escreve Livro (2012). A história do romance inicia-se com a entrega de um livro, objeto que atravessará toda a narrativa. De mãos em mãos, viajando entre tempos e espaços, o objeto carrega consigo a simbologia que nutre e concentra toda energia de expectativas malogradas, desejos não cumpridos, esperanças renovadas. Estes sentimentos são a matéria de um romance que reconstrói o cenário de emigração portuguesa para França, a partir do final da década de 60. O romance, estruturalmente, divise-se em duas partes, sendo que na primeira, foco deste trabalho, conhecemos a história de Ilídio, abandonado pela mãe aos seis anos de idade, que então emigrava para França. Ilídio é deixado para trás apenas com uma pequena mala e o livro dado por ela.

Ainda jovem Ilídio conhece uma garota por quem se apaixonará por toda a vida: Adelaide, uma moça simples que se mudara para a mesma aldeia para viver com uma velha tia, a Lubélia:

se namorares comigo, dou-te um pombo, cem escudos e um livro. Ilídio. Ela temia o que desejava. Tentou distinguir um cheiro por baixo do suor que repassava o papel. O amor, ela sempre sonhara com essa palavra, essa ideia. Agora podia começar a vivê-la. (PEIXOTO, 2012, p. 61).

A França surgirá na vida de ambos como cenário de mudança obrigatória e também de separação. Lubélia, interessada em separar os jovens enamorados, leva a cabo o plano de mandar Adelaide para a França, a fim de que a moça fosse trabalhar e ganhar dinheiro. A primeira parte da história, basicamente, gira em torno da relação amorosa entre Adelaide e Ilídio e do desencontro de ambos gerado pelo plano de Lubélia.

O Ilídio chegou primeiro e ficou na esquina do beco, ao sol. Segurava o livro na mão direita e tinha o outro braço apertado de encontro ao peito. Esperou e viu-a chegar com uma alcofa vazia. Apreciou os passos dela [...]. Como se desaparecessem, entraram no beco. Não havia tempo [...]. Na sombra, o pombo, os cem escudos. Estavam à sós pela primeira vez, havia detalhes na respiração. O Ilídio estendeulhe o livro [...]. Já eram completamente namorados (PEIXOTO, 2012, p. 70).

Descoberto o plano por Ilídio, o rapaz decide também deixar a sua aldeia na companhia de um amigo, o Cosme. A partir de então, um narrador em $3^{\text {a }}$ pessoa concentra-se no cenário da emigração, tomando como amostra, a descrição da viagem empreendida por Adelaide e Ilídio.

Volume 18

Número 40 


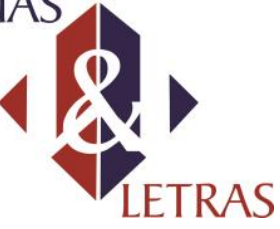

Ao engolir a primeira dentada, os ouvidos da Adelaide desentupiramse, abriram-se. Então, foi como se o mundo mudasse, como se crescesse, como se a distância se tornasse real de repente. A camioneta progredia, esforçava-se por entre campos de oliveiras. A cada buraco da estrada, saltavam dentro da camioneta [...]. Numas vezes, dava guinadas para se afastar de algum buraco. Noutras vezes, desistia de tentar. As mulheres saltavam uma para cada lado ou chocavam no ar com os ombros, davam cabeçadas no teto (PEIXOTO, 2012, p. 92-93).

O relato da viagem feita por Adelaide sugere um momento de epifania. Num destes sobressaltos, Adelaide cai sobre o banco da cabine "com a boca cheia de maçã mastigada" (PEIXOTO, 2012, p. 93), momento em que se apercebe do que lhe estava a acontecer "e chorou como uma cachopa" (PEIXOTO, 2012, p. 93).

A Adelaide só soube que ia para a França, quando a camioneta parou debaixo de um sobreiro, no meio da noite, quando pisou a terra. Foi a mulher que lhe disse [...]. A partir daquele ponto, seguiam a pé. As veredas eram concretas, separadas por tojos, feitas de terra macia e pedras. As duas mulheres e os homens seguiam em fila (PEIXOTO, 2012, p. 97).

O romance descreve as duras condições dos que partiram clandestinamente para França, evidenciando os trajetos poucos seguros, feitos pela madrugada, muito antes do sol nascer. Entre sobressaltos, acidentes, os grupos seguiam em meio ao desconforto, muitas vezes à sorte de caronas, à mercê do cansaço e do frio:

eram uma pequena multidão de desconhecidos assustados. As malas doíam os pés, as pernas ou a espinha. Arrastavam uma vontade que era cada vez mais difícil de explicar, náufragos de todas as palavras que não diziam, manchas cinzentas a atravessarem campos, a esconderem-se. Entre eles seguia a Adelaide, pensamentos misturados com mágoa e pó (PEIXOTO, 2012, p. 106).

A narrativa também sugere a ignorância e o alheamento de muitos dos que seguiam para a França. O romance de José Luís Peixoto não ostenta nenhuma bandeira e não se coloca em defesa de nenhuma ideologia. O seu Livro trata da história prosaica de dois jovens enamorados, que tem por traz dela outra importante história: a da emigração de um povo dado à aventura pelo desconhecido desde tempos muito antigos. Em Livro, os que seguiam para além dos Pirineus, mal sabiam para onde iam e o que lhes esperava no novo país. O que Adelaide sabia, de fato, sobre a França?

A Adelaide sabia três coisas acerca do país para onde se dirigia: na França, as pessoas tinham máquinas que faziam a lida da casa, que varriam o chão, que lavavam a loiça e a roupa, braços de ferro; na França, as pessoas só andavam de automóvel, mesmo para ir à 


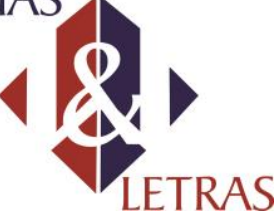

padaria; na França, as pessoas comiam carne de cavalo cozida [...]. Também já tinha ouvido falar da cidade de Paris, conhecia o nome, e também já sabia que os franceses falavam estrangeiro (PEIXOTO, 2012, p. 108).

Uma vez na França, Adelaide segue na companhia de uma amiga que fizera durante a viagem: Libânia, uma portuguesa do norte que ia a França onde o marido já estava. Adelaide aceita o convite dela e vai morar com eles: "Tímida, a Adelaide seguiu-os" (PEIXOTO, 2012, p. 130).

À entrada da estação, subiram para cima de uma camioneta cheia de homens e mulheres agarradas a crianças ranhosas, babosas. Essa camioneta havia de levá-los à casa do marido da Libânia. Durante o caminho de avenidas, a Adelaide e uma multidão de rostos, encavalitados em bagagens e uns nos outros, olhavam para todos os lados. Paris era uma cidade nova, pronta a estrear. As casas que viam, enormes, eram novas, pintadas com aprumo. Já tinha caído a noite, mas havia tanta luz que parecia de dia, estava mais claro do que muitas manhãs de inverno (PEIXOTO, 2012, p. 130).

O local, Saint-Denis, para onde os emigrantes iam era afastado de Paris, a uma hora de viagem ou duas, as ruas eram de terra e "as casas estavam rodeadas por casas com paredes de chapa de madeira, remendos de lata enferrujada, pregos tortos, arame" (PEIXOTO, 2012, p. 130-131). Já Ilídio e Cosme, quando finalmente conseguem atravessar os Pirineus e chegam a Paris, vão para Lagny, região que fica a aproximadamente $40 \mathrm{~km}$ de distância de Saint-Denis, ou mais ou menos, 38 minutos de carro.

A narrativa não deixa de evidenciar a dura vida levada pelos jovens. Ilídio, que conseguiu trabalho como pedreiro, "vivia em Lagny numa casa de quatro homens, quatro quartos, uma cozinha com comida estragada e uma casa de banho sem asseio" (PEIXOTO, 2012, p.155). Adelaide acordava às cinco da manhã para dirigir-se à casa que trabalhava como empregada de um casal de aposentados franceses. Tempos depois, consegue trabalho em uma biblioteca: "era um trabalho de limpezas, fácil, a biblioteca criava pouco lixo" (PEIXOTO, 2012, p. 147), passando, assim, a cumprir dupla jornada.

É nessa biblioteca que Adelaide conhece Constantino, filhos de portugueses a viver na França, com quem se casa. Foi pelo livro de Adelaide, colocado à disposição para leitura, que Constantino chegou ao destino de Adelaide. Depois de muitas cartas não respondidas e de perder a esperança de rever o seu antigo amor, Ilídio, Adelaide sentiu-se livre para casar-se com Constantino. A partir de então, a narrativa centra-se na descrição de todo o esforço de Ilídio à procura de Adelaide. Nesse sentido, o foco não é 


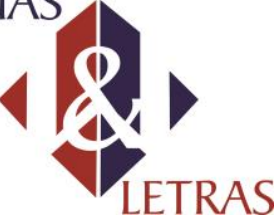

exatamente o mal-estar causado pelo desconforto da adaptação em França, ou pelas saudades da terra natal, pelo contrário, Ilídio demonstrava, principalmente nas cartas escritas para Josué, seu tutor em Portugal, que estava se adaptando bem e falava com entusiasmo da nova terra:

O Ilídio tinha esmorecido depois das cartas que escrevera à Adelaide e ao Josué [...]. Houve uma dessas cartas, a última, que seguiu dentro de um envelope endereçado ao Josué, pedindo que tentasse enviar-lha. Mas nada. Nem o próprio Josué respondera às cartas que lhe dirigira pessoalmente, em que lhe falava das grandes obras que se faziam na França (PEIXOTO, 2012, p. 154-155).

Ou seja, o desconforto é gerado pelo desencontro amoroso, pelo cansaço da procura, pela esperança que pouco a pouco se esvaía.

O desânimo total [...] instalou-se quando já se tinha cansado a calcorrear todos os barros de portugueses na região de Paris, quando já tinha passado domingos inteiros na Gare de Austerlitz a ver comboios chegarem e partirem, quando já se tinha aproximado de muitas mulheres que, junto ao Sena, à distância, pareciam mesmo ela mas que, depois, ao perto, não eram. O rosto de Ilídio era diferente quando, no final desses domingos, voltava para Champigny, a sua melhor roupa pendurada no corpo magro (PEIXOTO, 2012, p. 155).

Quando finalmente os destinos de Ilídio e Adelaide se cruzam em França, ela já está compromissada com Constantino. Depois do casamento, Adelaide continua a levar a mesma vida, dividida entre a biblioteca e a casa francesa. Ilídio retorna provisoriamente a Portugal levando consigo as economias poupadas com o trabalho em França: "no dia 10 de abril de 1968, quando soube que tinha passado a fronteira, o Ilídio abriu a janela do vagão [...]. Pensava no Josué a admirar-se da sua chegada" (PEIXOTO, 2012, p.176). Não há também indícios de mal-estar na volta de Ilídio à aldeia. A narrativa dá mostras de que ele é bem recebido pelos da aldeia e de que não há estranhamento por sua chegada, nem mesmo há necessidade de readaptação por parte dele, ausente de sua terra por aproximadamente quatro anos, mas esperado com grande entusiasmo e admiração pelas pessoas da vila "essa admiração repetiu-se muitas vezes" (PEIXOTO, 2012, p.182).

Ilídio vai cumprir exatamente os planos dos que depois da estada na França decidiam fazer no regresso a Portugal. O que parece comumente partilhado e compreendido é que a permanência na sociedade de acolhimento era temporária; residir em França “[era] sinónimo de um tempo/espaço provisório que [visava] alcançar objetivos precisos como, por exemplo, a construção de uma casa em Portugal, assegurar 


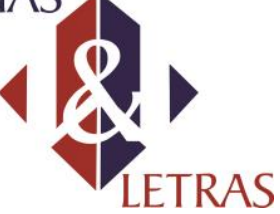

e-ISSN: 1981-4755

DOI: $10.5935 / 1981-4755.20170012$

uma situação de estabilidade económica/financeira em Portugal, [...] para talvez um dia regressar" (AFONSO, A Segunda Geração $e$ o Regresso [on line] http://www.ces.fe.uc.pt/). Ele decide comprar um terreno para construção de uma casa. E para ajuntar mais fundos, volta para a França mais uma vez, deixando a obra nas mãos de Josué.

Em 1973, Adelaide consegue permissão de seu marido para visitar a vila, onde Ilídio passara a visitar todos os verões. O jovem prosperava, já estava amealhando economias para a compra de um carro e a construção da casa dava-se por encerrada. Com a ida de Adelaide à aldeia, os antigos namorados acabam se reencontrando numa festa: "era inevitável, à distância, a Adelaide e o Ilídio fixaram-se” (PEIXOTO, 2012, p. 214). De modo que a distância dos corpos não resistira a aproximação dos olhos, logo:

\begin{abstract}
A Adelaide contornou o muro da d. Milú e desceu em direção à fonte nova. O Ilídio sentiu gelo arrumado às raízes dos dentes [...]. A Adelaide desapareceu atrás do chafariz. O Ilídio não temeu o arrulhar das águas e desapareceu no mesmo ponto, atrás do muro. Era uma noite de agosto, os grilos [...]. Quando a Adelaide saiu de trás do muro do chafariz, já uma vírgula iniciara o percurso em direção ao seu útero (PEIXOTO, 2012, p. 216).
\end{abstract}

A gestação de Livro, o filho que Adelaide terá com Ilídio, ocorre durante o ano de 1974. Adelaide já está em França e Constantino, que mais tarde enlouquecerá, nunca saberá que não é o pai biológico dessa criança. O cenário de abril de 1974, tão importante e decisivo para o povo português, dilui-se com a cena de Adelaide em casa, a aproveitar a tranquilidade dos dias da gravidez. Naquele mesmo dia, Constantino e ela: "jantaram qualquer coisa. Ele leu qualquer coisa. Ela pensou em qualquer coisa. Foram dormir" (PEIXOTO, 2012, p.218). No dia 27 de abril nasce Livro e, a partir desse momento, tem início a segunda parte do romance, sendo que a narração passa a ser na $1^{\text {a }}$ pessoa, na voz do protagonista, filho de Adelaide e Ilídio.

A escrita ficcional portuguesa contemporânea tem atendido ao apelo da relativização das verdades e dos fatos tanto do presente como, sobretudo, do passado recente. Tal procedimento faz-se em consonância ao desejo de muitos autores de retratar, por vias literárias, não mais um Portugal fechado sobre si próprio, mas antes, um Portugal global, com tendências sociais e problemas psicológicos semelhantes aos dos europeus. Sem lançar "ensinamentos ou apresentar modelos de comportamento morais", sem claramente defender pontos de vistas críticos ou conteúdos ideológicos 


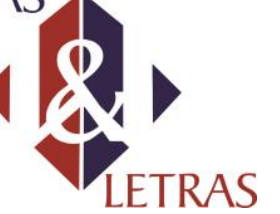

e-ISSN: 1981-4755

DOI: $10.5935 / 1981-4755.20170012$

específicos (REAL, 2012, p. 53), temos uma ficção voltada para o cosmopolitismo e dirigida para um público universal.

Dessa forma, o que se nota é que o romance de José Luís Peixoto centra-se sobretudo nos encontros e desencontros das vidas e dos destinos. A temática da diáspora portuguesa em França serve de mote para que nos voltemos para a natureza humana e para a dor. Centrando-se na angústia da separação e no amor nutrido entre Ilídio e Lubélia, a história do romance, revestida de um lirismo característico de José Luís Peixoto, faz com que o plano ideológico contido na questão da emigração dê lugar para questões universalizantes. Daí a sensação de que a adaptação dos emigrantes em França seja descrita com menos crueza se a compararmos ao romance de Júlia Nery. Também não se nota nas páginas de Livro, a permanente tensão espacial experimentada tanto pelo protagonista d'O retorno quanto por Leonor, a jovem protagonista de Pouca terra... poucá terra. As sensações de desconforto no romance de José Luís Peixoto ligam-se, portanto, às circunstâncias dos desencontros e das saudades, numa clara tentativa de mistificação da realidade.

Parece-nos que, no caso de Rui ou de Leonor, os sentimentos e crises de nãopertencimento estão ligados sobretudo à questões existenciais próprios dos que se viram na obrigação do regresso. O que não se aplica a Ilídio, que retornou a Portugal com a algibeira cheia para construção de sua casa, depois para compra de um carro e com fundos que lhe garantiram uma velhice confortável. Assim, depreendemos que, no romance de José Luís Peixoto, é imperativa a questão do amor inocente, dos sentimentos guardados na infância, o que confere à história certa sensibilidade pueril, metaforizada na aldeia onde as personagens vivem, saem e depois regressam. Sem dúvida alguma, Livro serve-nos de contraponto à questão do não-pertencimento vivenciada por Rui e Leonor. Tanto n'O retorno quanto em Pouca terra...poucá terra, as questões existenciais ligadas ao desconforto do não-pertencimento têm maior relevância. Rui e Leonor são dois jovens que não pertencem nem a seus lugares de origem, nem aos novos lugares que passam a habitar. No caso de Leonor, continuaria a ser portuguesa em França e francesa em Portugal - a sua crise, sobretudo existencial, esteve ligada, de um lado, ao sentimento de incapacidade de gerir o seu futuro e, de outro, pela indecisão da escolha entre voltar para Portugal ou ficar definitivamente na França. Para Rui, restou-lhe o rótulo de retornado, vivenciando uma espécie de angústia ligada ao idílio deixado para trás: Luanda, e a terra nova, que não lhe ofereceu, ao menos inicialmente, segurança e estabilidade. 


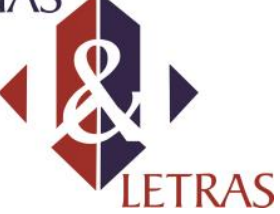

e-ISSN: 1981-4755

DOI: $10.5935 / 1981-4755.20170012$

De qualquer modo, notamos que a questão diaspórica é tomada pelos três autores como mote para a observação da matéria humana. Quanto mais se aproximam de certos períodos da história recente portuguesa, mais se avizinham dos sentimentos de que são feitos seus protagonistas. Para além dos conteúdos ideológicos de crítica às mazelas ou benesses do império e de seu fim, vemos sobressair a história de pessoas comuns, uma de nome Rui, outra de nome Ilídio, outra de nome Leonor, que têm como ponto em comum nas suas histórias a dor, seja relativa ao mal-estar na adaptação em terra alheia, seja na frustração dos desencontros amorosos. A identificação desse sentimento situado em tempos e espaços distintos estatui-nos como seres humanos universais, objetivo que, como afirmamos inicialmente, parece ser um dos mais evidentes da literatura portuguesa contemporânea.

\section{REFERÊNCIAS}

AFONSO, Sofia C. A Segunda Geração e o Regresso. Geografia do Actor de Fronteira [on line]. Disponível em <http://www.ces.fe.uc.pt/ > . Acesso em 10 de março de 2015. CARDOSO, Dulce Maria. O retorno. Lisboa: Edições Tinta da China, 2011.

HALL, Stuart. Da diáspora: Identidades e mediações culturais. Belo Horizonte: Ed. UFMG, 2011.

NERY, Júlia. Pouca terra...poucá terra... Lisboa: Rolim, 1984.

LOURENÇO, Eduardo. Mitologia da saudade: seguido de Portugal como destino. São Paulo: Companhia das Letras, 1999.

MACHADO, Alleid R. Entrevista - Dulce Maria Cardoso e Júlia Nery: olhares em torno da diáspora portuguesa em França e África. Revista Desassossego. Periódico do programa de pós-graduação em Literatura Portuguesa da USP, São Paulo, v. 6, n. 12, p. 95-119, dez. 2014.

PEIXOTO, José Luís. Livro. São Paulo: Companhia das Letras, 2012.

REAL, Miguel. O romance português contemporâneo: 1950 - 2010. 2 ed. Alfragide: Editorial Caminho, 2012.

SAID, Edward. Reflexões sobre o exílio e outros ensaios. Trad. Pedro Maia Soares. São Paulo: Companhia das Letras, 2003.

SERRÃO, Joel. A emigração portuguesa: Sondagem histórica. 4 ed. Lisboa: Livros Horizonte, 1982. 